\title{
Ефективність комплексної програми фізичної реабілітації хворих на бронхіальну астму в поєднанні з патологією гепатобіліарної системи
}

\author{
УдК: 616.711:616.248:616.3 \\ В. В. Клапчук, Н. В. Марюхніч, Т. Ю. Фоменко
}

Національний університет «Запорізька політехніка», Запоріжжя, Україна

\begin{abstract}
Резюме. Мета. Науково обґрунтувати, розробити і визначити ефективність комплексної програми фізичної реабілітації хворих на бронхіальну астму в поєднанні з патологією гепатобіліарної системи.

Методи. Розрахунок індексу Робінсона (подвійного добутку) для оцінки обмінноенергетичних процесів в міокарді; розрахунок адаптаційного потенціалу серцево-судинної системи, вегетативного індексу Кердо, експіраторного гіпоксичного індексу, інтенсивності болю за допомогою візуально-аналогової шкали ВАШ та психоемоційного стану за тестом САН. Результати. Обстежено 20 осіб віком від 36 до 60 років (з них 10 жінок і 10 чоловіків) з діагнозом бронхіальна астма і супутніми патологіями гепатобіліарної системи. у реабілітаційному комплексі використано лікувальну гімнастику, яка відрізнялась поєднанням спеціальних фізичних вправ для бронхіальної астми та патології гепатобіліарної системи, способи вольового керування диханням для профілактики та купірування бронхоспазму, сегментарно-рефлекторний та точковий масаж, фізіотерапію, дієтотерапію. Висновки. Під впливом проведеного курсу фізичної реабілітації у експериментальній групі достовірно покращились показники психологічного тесту САН (з 40,2 \pm 1,89 до 49,5 \pm 2,01 ум. од.;

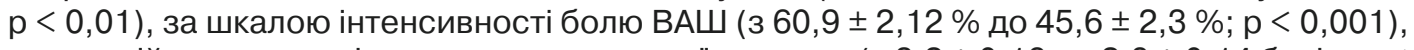
адаптаційного потенціалу серцево-судинної системи (з 3,2 $\pm 0,16$ до 2,8 \pm 0,14 балів; $p<0,05)$, а також індексу Робінсона (з 101,4 $\pm 3,4$ до 93,2 $\pm 2,46$ ум. од.; $p<0,05$ ) та експіраторного

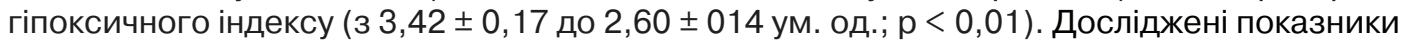
функціональних резервів організму хворих на бронхіальну астму, яка поєднується з патологією гепатобіліарної системи, у основній групі кращі, ніж у контрольній. В основній групі було виявлено більш суттєвий реабілітаційний єфект, що доказує ефективність та переваги розробленої реабілітаційної програми і дозволяє рекомендувати її до впровадження.

Ключові слова: фізична реабілітація, бронхіальна астма, гепатобіліарна система.
\end{abstract}

Effectiveness of the integrated physical rehabilitation program for patients with bronchial asthma combined with hepatobilary system pathology

\section{V. Klapchuk, N. V. Mariukhnich, T. Y. Fomenko}

«Zaporizhzhya Polytechnic» National University

Abstract. Objective. To scientifically substantiate, develop and determine the effectiveness of complex physical rehabilitation program for patients with bronchial asthma combined with the pathology of the hepatobiliary system.

Methods: calculation of the Robinson index (double product) for assessing metabolic and energy processes in the myocardium, the adaptive potential of the cardiovascular system, the autonomic Kerdo index, expiratory hypoxic index, pain intensity using the visual analogue scale VASH and psychoemotional state according to SAN test. Results. We examined 20 people aged 36-60 years ( 10 women and 10 men) with a diagnosis of asthma and concomitant pathologies of the hepatobiliary system. The rehabilitation complex contained therapeutic gymnastics, which was distinguished 
by a combination of special physical exercises for bronchial asthma and pathology of the hepatobiliary system, methods of volitional breathing control for prevention and relief of bronchospasm, reflexosegmental and acupuncture massage, physiotherapy, and diet therapy. Conclusions. Under the influence of the course of physical rehabilitation in the experimental group, the SAN psychological test indices significantly improved (from $40.2 \pm 1.89$ to $49.5 \pm 2.01$ conv. un.; $p<0.01$ ), according to the VASH pain intensity scale ( from $60.9 \pm 2.12 \%$ to $45.6 \pm 2.3 \% ; p<0.001$ ), the adaptive capacity of the cardiovascular system (from $3.2 \pm 0.16$ to $2.8 \pm 0.14$ points; $p<0.05$ ), and the Robinson index (from 101.4 \pm 3.4 to $93.2 \pm 2.46$ conventional units; $p<0.05$ ) and expiratory hypoxic index (from $3.42 \pm 0.17$ to $2.60 \pm 014$ conventional units; $p<0,01$ ). Examined indices of the body functional reserves of patients with bronchial asthma combined with the pathology of the hepatobiliary system are better in the main group than in the control one. More significant rehabilitation effect was observed in the main group, which proves the effectiveness and advantages of our rehabilitation program, thus allowing to recommend its implementation.

Keywords: physical rehabilitation, bronchial asthma, hepatobiliary system.

Постановка проблеми. В усіх країнах світу протягом останніх 20-30 років відзначається значне зростання захворюваності на бронхіальну астму (БА). У спортсменів вона може мати такі френотипи: атопічний, індукований вірусними і бактеріальними антигенами та викликаний фрізичними навантаженнями. Крім цього, у спортсменів можуть розвиватися такі стани, як синдроми дисфункції голосових зв'язок та риніту, які потребують диференціальної діагностики з БА $[4,6,7,10]$.

Поширеність БА в Україні серед дорослих становить 7-8 \% [4]. При цьому спостерігаються більш тяжкий перебіг хвороби, поява гормонозалежних форм, рання інвалідизація і смертність, а також збільшення кількості хворих з поєднаним ураженням різних органів та систем. Ряд авторів вважають, що у зв'язку з поліморфізмом проявів БА це захворювання є синдромом, який об'єднує групу хвороб, що розвиваються у осіб, схильних до них, під впливом алергенів, інфекцій, псевдоалергенів, і характеризується гіперреактивністю бронхів, зворотною їх обструкцією з клінічними проявами у вигляді нападів експіраторної ядухи і еозинофілії [2].

Зараз спостерігається тенденція зростання поєднаних алергічних захворювань. У 98 \% випадків поєднана алергічна патологія пов'язана 3 ураженням органів травлення, що призводить до всмоктування неповністю розщеплених компонентів їжі, формування гіперчутливості до харчових, побутових, епідермальних, пилкових алергенів $[2,5]$. Відомо, що шлунково-кишковий тракт $\epsilon$ найпотужнішим імунним та лімфопоетичним (тобто продукує лімфоцити) органом, що забезпечує адаптацію організму до речовин, що надходять 3 їжею, а печінка відіграє основну роль у регуляції рівня антигенів, які надходять 3 просвіту кишечника або інших органів у системний кровоток, а 3 нього - в лімфоїдні органи. Таким чином, клітини печінки асоційовані з широким спектром біологічно активних молекул, які відіграють важливу роль у процесах запалення та імунітету [2].

У патогенезі алергічних та псевдоалергічних проявів значна роль належить порушенню гепатобіліарної системи (застій жовчі викликає порушення бар'єрної і детоксикаційної функції печінки, що збільшує антигенне навантаження на імунну систему і призводить до ураження ії компонентів токсичними сполуками, які надходять 3 травного тракту) $[2,5]$.

Незважаючи на досягнуті за останні роки успіхи в діагностиці, лікуванні та профрілактиці цих хвороб, завдяки широкому впровадженню міжнародних та національних узгоджувальних документів, багато аспектів поєднанання бронхіальної астми та патології гепатобіліарної системи у дорослого населення залишаються недостатньо ясними, а реабілітаційні заходи далекі від досконалості. В зв'язку з цим проблема профілактики, діагностики та відновного лікування цього захворювання з використанням диференційованих засобів фрізичної реабілітації набуває надзвичайної важливості.

Мета дослідження: науково обгрунтувати, розробити і визначити ефективність комплексної програми фрізичної реабілітації хворих на бронхіальну астму в поєднанні з патологією гепатобіліарної системи.

Матеріали та методи дослідження. В дослідженні, проведеному у на базі 8 міської клінічної лікарні (Запоріжжя), взяли участь 20 осіб другого зрілого віку від 36 до 60 років (10 жінок i 10 чоловіків) з діагнозом БА, що мали супутню патологію гепатобіліарної системи. Методом випадкової вибірки обстежених було розподілено на основну і контрольну групи по 10 осіб у кожній $з$ урахуванням основного і супутнього діагнозів. Достовірної різниці між групами пацієнтів за досліджуваними показниками на початку дослідження не спостерігалося. 
Функціональний стан серцево-судинної системи оцінювали за такими гемодинамічними показниками, як частота серцевих скорочень (ЧСС), що визначалась за допомогою пульсометрії на променевій артерії, та артеріальний тиск (AT), який вимірювали тонометром на плечовій артерії за методом Короткова. Отримані результати застосували для розрахунку індексу Робінсона (подвійного добутку), який дозволяв оцінити рівень обмінно-енергетичних процесів у міокарді [8]. Використовували формулу: IP = ЧСС х САТ : 100 і оцінювали в умовних одиницях за такими градаціями: низький - понад 111, нижче середнього - 110-95, середній - 94-85, вище середнього - 84-70, високий - менше 70.

Розрахунок адаптаційного потенціалу серцево-судинної системи проводили за фрормулою:

$$
\begin{gathered}
A \Pi=0,0011(4 \mathrm{CC})+0,014(\text { САТ })+ \\
+0,008 \text { (ДАТ) }+0,009(\mathrm{MT})-0,009(\mathrm{P}) \\
+0,014(\mathrm{~B})-0,27,
\end{gathered}
$$

де АП - адаптаційний потенціал (ум. од); ЧСС - частота серцевих скорочень (уд. хв $\left.^{-1}\right)$; САТ - систолічний артеріальний тиск (мм рт. ст.); ДАТ - де АП - адаптаційний потенціал системи кровообігу в балах, ЧСС - частота пульсу (уд. - хв ${ }^{-1}$ ); САТ і ДАТ - систолічний та діастолічний артеріальний тиск (мм рт. ст.); Р - довжина тіла (см); МТ - маса тіла (кг); В - вік (роки).

Критерії оцінки АП: 2,6 і нижче - задовільна адаптація; 2,6-3,9 - напруження механізмів адаптації; 3,1-3,49 - незадовільна адаптація; 3,5 і вище - зрив адаптації [8].

Для визначення стану вегетативної нервової системи розраховували індекс Кердо за такою фрормулою:

$$
\text { IК = (САТ-ДАТ) : ЧСС, }
$$

де IK - індекс Кердо; САТ - систолічний артеріальний тиск; ДАТ -діастолічний артеріальний тиск, ЧСС - частота серцевих скорочень.

У нормі цей показник близький до одиниці. Позитивні значення вказують на перевагу симпатичної регуляції тонусу судин, негативні - парасимпатичної [1].

Стійкість організму до гіпоксії оцінювали за допомогою експіраторного гіпоксичного індексу (ЧСС, уд. хв : проба Генча, с) [8].

Для вимірювання інтенсивності болю застосувавали візуально-аналогову шкалу ВАШ (Visual Analog scale). Вона являє собою безперервну шкалу у вигляді горизонтальної чи вертикальної лінії довжиною 10 см (100 мм) 3 розташованими на ній двома крайніми точками: «відсутність болю» і «найсильніший біль, який можна тільки уявити». Пацієнту пропонували розмістити лінію, яка перпендикулярно перетинає візуально-аналогову шкалу в тій точці, яка відповідає інтенсивності його болю. За допомогою лінійки вимірювали відстань (мм) між точками «відсутність болю» і «найсильніший біль, який можна тільки уявити», забезпечуючи діапазон оцінок від 0 до 100. Більш високий бал вказував на більшу інтенсивність болю [3].

Оцінювання психоемоційного стану проводили за тестом САН шляхом співвіднесення обстежуваними свого стану з ознаками самопочуття, активності та настрою за багатоступінчастою шкалою,

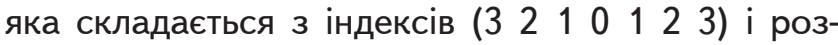
ташована між тридцятьма парами слів протилежного значення. Вони відображують рухливість, швидкість і темп протікання фрункцій (активність), силу, здоров'я, стомлення (самопочуття), а також характеристики емоційного стану (настрій) [3].

Отримані результати були оброблені за допомогою прикладних і статистичних програм «Microsoft Excel 2007» та «Statistica 6.0». Розраховували середнє (M) та його стандартну помилку $(\mathrm{m})$. Достовірність різниці (p) оцінювали за критерієм Стьюдента (t) [9].

Реабілітаційний курс основної і контрольної груп включав в себе дієтотерапію, ранкову гігієнічну гімнастику, лікувальну гімнастику, масаж та фрізіотерапію. Для пацієнтів основної групи нами було запропоновано лікувальну гімнастику, яка відрізнялась поєднанням спеціальних фрізичних вправ, що застосовують при БА та при патології гепатобіліарної системи. У цій групі також застосовували розроблені за нашою участю способи вольового керування диханням для профрілактики та купірування нападів ядухи. В основній групі, на відміну від контрольної, використовували сегментарно-рефлекторний та точковий масаж, а у контрольній - класичний (на курс 12 процедур через день). При цьому масаж проводили за 1,5-2 год. до процедури лікувальної гімнастики, оскільки зазначений інтервал суттєво збільшує фрункціональні можливості дихальної системи хворого і дозволяє повніше реалізувати лікувальний і тренувальний ефекти фрізичних вправ. Також для пацієнтів основної групи нами було підібрано і розроблено дієтотерапію, розраховану на хворих з БА та патологією гепатобіліарної системи на основі столу № 9 та столу № 5. Водночас нами було розроблено приблизне меню на тиждень, якого дотримувалися пацієнти основної групи під час реабілітації. Паціенти контрольної групи проходили загальноприйнятий курс фрізич- 
ТАБЛИЦЯ 1 - Динаміка показників психофізичного стану у пацієнтів основної групи при фізичній реабілітації

\begin{tabular}{|l|c|c|c|c|c|}
\hline \multirow{2}{*}{\multicolumn{1}{|c|}{ Показник }} & \multicolumn{2}{|c|}{ Первинні (n = 10) } & \multicolumn{3}{|c|}{ Прикінцеві (n = 10) } \\
\cline { 2 - 6 } & $\mathbf{M}$ & $\mathbf{M}$ & $\mathbf{M}$ & $\mathbf{~ M}$ & $\mathbf{p}$ \\
\hline $\begin{array}{l}\text { Індекс Робінсона, } \\
\text { ум. од. }\end{array}$ & 101,4 & 3,04 & 93,2 & 2,46 & $<0,05$ \\
\hline $\begin{array}{l}\text { Адаптаційний } \\
\text { потенціал, бали }\end{array}$ & 3,2 & 0,16 & 2,8 & 0,14 & $<0,05$ \\
\hline $\begin{array}{l}\text { Індекс Кердо, } \\
\text { ум. од. }\end{array}$ & 0,73 & 0,036 & 0,71 & 0,032 & $>0,05$ \\
\hline $\begin{array}{l}\text { Гіпоксичний } \\
\text { індекс, ум. од }\end{array}$ & 3,42 & 0,17 & 2,60 & 0,14 & $<0,01$ \\
\hline Шкала ВАШ, \% & 60,9 & 2,12 & 45,6 & 2,03 & $<0,001$ \\
\hline $\begin{array}{l}\text { Опитувальник } \\
\text { САН, бали }\end{array}$ & 40,2 & 1,89 & 49,5 & 2,01 & $<0,01$ \\
\hline
\end{tabular}

ної реабілітації, який використовувався на базі лікарні.

Результати досліджень та їх обговорення. Аналіз медичних карток показав, що пацієнтів у стадії загострення БА було - 85 \%, з середньотяжкою формою - $10 \%$ і з тяжкою - $5 \%$. Під час госпіталізації хворі скаржилися на погіршення загального самопочуття: кашель, задишка, хрипи в легенях, закладеність носа. У всіх обстежених виявлено дисфрункцію гепатобіліарної системи.

Під час первинного обстеження для психофрізичного стану пацієнтів було характерним таке: у середньому інтенсивність болю за шкалою ВАШ знаходилась у межах $60 \%$ максимально можливого рівня, психоемоційний стан за шкалою САН перевищував 40 балів, тобто був сприятливим, але норми не досягав. Індекс Робінсона становив у основній групі 101,4 $\pm 3,04$ ум. од, у контрольній - 103,5 \pm 4,17; адаптаційний потенціал $-3,20 \pm 0,16$ та 3,17 $\pm 0,14$ ум. од.; експіраторний гіпоксичний індекс $-3,42 \pm 0,17$ та $3,13 \pm 0,16$ ум. од.; вегетативний індекс Кердо $0,73 \pm 0,036$ та 0,75 $\pm 0,38$ ум. од. відповідно до груп ( $>>0,05)$. Величини індексу Робінсона та гіпоксичного індексу були нижче середніх, адаптаційного потенціалу серцево-судинної системи - свідчили про напруження механізмів адаптації, а індексу Кердо - про переважання парасимпатичної регуляції тонусу судин $[1,3,8]$. Отримані результати відрізняються новизною. Вони дозволили оцінити вихідний функціональний резерв досліджених фрізіологічних систем за окремими складовими гемодинаміки, респірації та нервової регуляції у хворих на БА, яка поєднувалась $з$ патологією гепатобіліарної системи.

У цілому отримані результати первинних досліджень свідчили про придатність для порівняння експериментальної та контрольної груп як таких, що не мали статистично значущої різниці досліджених показників.

Після реабілітаційного курсу у контрольній групі ми отримали статистично достовірні позитивні зміни тільки в ході оцінки динаміки психоемоційного стану за тестом САН та за шкалою відчуття болю ВАШ. У основній групі, крім цих показників зазнали статистично достовірних позитивних змін показники індексу Робінсона $(p<0,5)$, адаптаційного потенціалу $(p<0,05)$, експіраторного гіпоксичного індексу $(p<001)$. Зменшення абсолютних значень усіх досліджених показників, крім тесту САН, свідчить про позитивні зміни (табл. 1).

Додатково проведено порівняння між групами досліджених показників після курсу фрізичної реабілітації (табл. 2). 3 таблиці 2 видно, що за індексом Робінсона після курсу ффізичної реабілітації позитивні зміни обмінно-енергетичних процесів у міокарді, що відбулися під впливом розробленої методики, переважають у пацієнтів основної групи ( $t=2,40 ; p<0,05)$. Адаптаційний потенціал серцево-судинної системи, якого досягнуто при фрізичній реабілітації у основній групі, теж переважав контрольну $(t=3,33 ; p<0,05)$, як і рівень стійкості до гіпоксії ( $\mathrm{t}=2,34 ; \mathrm{p}<0,05)$. У основній групі інтенсивність болю стала достовірно нижче порівняно з контрольною групою, що видно з тесту ВАШ $(\mathrm{t}=2,03 ; \mathrm{p}<0,05)$. В основній групі порівняно 3 контрольною психоемоційний стан за тестом САН виявився достовірно кращим, ніж у контрольній групі $(\mathrm{t}=2,56$; $\mathrm{p}<0,05)$.

В обох групах після реабілітаційного курсу стабілізувалась вегетативна регуляція, але ії статистично достовірної різниці за індексом Кердо між групами не виявлено $(t=1,35 ; p>0,05)$.

ТАБЛИЦЯ 2 - Порівняльний аналіз показників психофізичного стану у контрольній та основній групах після проведення курсу фізичної реабілітації

\begin{tabular}{|l|c|c|c|c|c|}
\hline \multirow{2}{*}{\multicolumn{1}{|c|}{ Показник }} & \multicolumn{2}{|c|}{$\begin{array}{c}\text { Контрольна } \\
\text { група (n= 10) }\end{array}$} & \multicolumn{3}{c|}{$\begin{array}{c}\text { Основна } \\
\text { група (n=10) }\end{array}$} \\
\cline { 2 - 6 } & M & M & M & M & p \\
\hline $\begin{array}{l}\text { Індекс Робінсона, } \\
\text { ум. од. }\end{array}$ & 101,4 & 2,37 & 93,2 & 2,46 & $<0,05$ \\
\hline $\begin{array}{l}\text { Адаптаційний } \\
\text { потенціал, бали }\end{array}$ & 3,5 & 0,12 & 2,8 & 0,14 & $<0,05$ \\
\hline $\begin{array}{l}\text { Індекс Кердо, } \\
\text { ум. од. }\end{array}$ & 0,72 & 0,041 & 0,71 & 0,032 & $>0,05$ \\
\hline $\begin{array}{l}\text { Гіпоксичний } \\
\text { індекс, ум.од. }\end{array}$ & 3,09 & 0,15 & 2,60 & 0,14 & $<0,05$ \\
\hline Шкала ВАШ, \% & 51,9 & 2,07 & 45,6 & 2,03 & $<0,001$ \\
\hline $\begin{array}{l}\text { Опитувальник } \\
\text { САН, бали }\end{array}$ & 42,3 & 1,96 & 49,5 & 2,01 & $<0,01$ \\
\hline
\end{tabular}


Таким чином, досліджені показники функціональних резервів організму хворих на БА, яка поєднується з патологією гепатобіліарної системи, в основній групі кращі, ніж у контрольній. В основній групі було виявлено більш суттєвий реабілітаційний ефект, що свідчить про ефрективність та переваги розробленої нами реабілітаційної програми і дозволяє рекомендувати ії до впровадження.

\section{Висновки}

1. При поєднанні бронхіальної астми з патологією гепатобіліарної системи для психофрізичного стану хворих характерно таке: у середньому інтенсивність болю за шкалою ВАШ знаходилась у межах $60 \%$ максимально можливого рівня, психоемоційний стан за шкалою САН перевищував 40 балів, тобто був сприятливим, але норми не досягав. Індекс Робінсона становив у основній групі $101,4 \pm 3,04$ у контрольній $103,5 \pm 4,17$ ум. од.; адаптаційний потенціал $3,20 \pm 0,16$ та $3,17 \pm 0,14$ ум. од.; експіраторний гіпоксичний індекс $-3,42 \pm 0,17$ та $3,13 \pm$ \pm 0,16 ум. од.; вегетативний індекс Кердо $0,73 \pm 0,036$ та 0,75 $\pm 0,38$ ум. од. відповідно до груп ( $>>0,05)$. Величини індексу Робінсона та гіпоксичного індексу були нижче середніх; адаптаційного потенціалу серцево-судинної системи свідчили про напруження механізмів адаптації; індексу Кердо - про переважання парасимпатичної регуляції тонусу судин.

2. На відміну від традиційного підходу, для проведення фрізичної реабілітації запропоновано: лікувальну гімнастику, яка відрізнялась поєднанням спеціальних фрізичних вправ, що застосовують при БА та при патології гепатобіліарної системи; способи вольового керування диханням для проорілактики та купірування бронхоспазму; сегментарно-рефрлекторний та точковий масаж; дієтотерапію, розраховану на хворих з БА та 3 патологією гепатобіліарної системи на основі столу № 9 та столу № 5, а також приблизне меню на тиждень.

\section{Література}

1. Афранасьєва ОВ, Євдокімов ЄІ. Застосування індексу Кердо в практиці фізичного реабілітолога [Application of the Kerdo index in the practice of physical rehabilitation]. Проблеми фрізичного виховання і спорту. 2011; 4: 23-6.

2. Банди Солонго. Состояние функции печени, перекисного окисления липидов и антиоксидантной защиты у больных аспириновой астмой [The state of liver function, lipid peroxidation and antioxidant defense in patients with aspirin asthma] [автореферат]. Барнаул; $2004.28 \mathrm{c}$.

3. Белова АН, Щепетова ОН. Шкалы, тесты и опросники в медицинской реабилитации [Scales, tests and questionnaires in medical rehabilitation]. Москва: Антидор; 2002: С. 252-3.
3. Під впливом проведеного курсу фрізичної реабілітації у експериментальній групі достовірно покращились показники психологічного тесту САН (з 40,2 $\pm 1,89$ до 49,5 $\pm 2,01$ ум. од.; $\mathrm{p}<0,01)$, за шкалою інтенсивності болю ВАШ (з 60,9 $\pm 2,12$ до 45,6 \pm 2,03 \%; $p<0,001$ ), адаптаційного потенціалу (з $3,2 \pm 0,16$ до 2,8 \pm $\pm 0,14$ балів; $p<0,05)$, а також індексу Робінсона (з 101,4 $\pm 3,4$ до 93,2 $\pm 2,46$ ум. од.; $p<$ $<0,05)$ та експіраторного гіпоксичного індексу (з 3,42 $\pm 0,17$ до 2,60 $\pm 0,14$ ум. од.; $p<0,01$ ).

4. Досліджені показники функціональних резервів організму хворих на БА, яка поєднується 3 патологією гепатобіліарної системи, у основній групі кращі, ніж у контрольній. За індексом Робінсона після курсу фрізичної реабілітації позитивні зміни обмінно-енергетичних процесів у міокарді, що відбулися під впливом розробленої методики, переважають у пацієнтів основної групи порівняно з контрольною $(t=2,40 ; p<0,05)$. Адаптаційний потенціал серцево-судинної системи, якого досягнуто під час фрізичної реабілітації у основній групі, теж переважав контрольну ( $\mathrm{t}=$ $=3,33 ; p<0,05)$, як і рівень стійкості до гіпокciї $(\mathrm{t}=2,34 ; \mathrm{p}<0,05)$. У основній групі інтенсивність болю стала достовірно нижче порівняно 3 контрольною групою, що видно з тесту ВАШ $(\mathrm{t}=2,03 ; \mathrm{p}<0,05)$. Водночас у основній групі порівняно з контрольною психоемоційний стан за тестом САН виявився достовірно кращим, ніж у контрольній групі $(t=2,56 ; p<0,05)$. Це свідчить про ефективність та переваги розробленої нами реабілітаційної програми і дозволяє рекомендувати її до впровадження.

У подальшому доцільно диференційоване дослідження ефеективності відновного лікування хворих на бронхіальну астму у поєднанні з патологією гепатобіліарної системи на різних етапах реабілітації - стаціонарному, амбулаторно-поліклінічному та санаторному з урахуванням їх спадкоємності.

Конфлікт інтересів. Автори заявляють, що не існує ніякого конфрлікту інтересів.

4. Гунина Лариса. Бронхиальная астма физического напряжения проблемы профилактики и требования WADA [Exercise Bronchial Asthma: Prevention Problems and WADA Requirements]. Наука в олимпийском спорте. 2016; 2: 51-6.

5. Ефимова НЮ. Функциональное состояние печени у больных аспириновой бронхиальной астмой [Functional state of the liver in patients with aspirin bronchial asthma] [автореферат]. 1994. 22 c.

6. Курбанова ОМ. Бронхоспазм, вызванный физической нагрузкой: особенности течения и терапевтические подходы [Exercise-induced bronchospasm: course features and therapeutic approaches]. Астма и аллергия. 2018; 1: 17-21. 
7. Молостова ТН. Особенности назначения терапии бронхиальной астмы у спортсменов. [Features of the appointment of therapy for bronchial asthma in athletes]. Астма и аллергия. 2018; 4: 7-12.

8. Берестень НФ, Сандриков ВА, Федорова СИ, редакторы. Функциональная диагностика [Functional Diagnostics] (национальное руководство).Изд.группа «ГЭОТАР-Медиа»; 2019. 784 с.

vasiliy.klapchuk@gmail.com
9. Гланц Стентон. Медико-биологическая статистика [Biomedical statistics]; пер. с англ. Москва: Практика; 1999. 459 с.

10. Cowie RL, Conley DP, Underwood MF, et al. A randomised controlled trial of the Buteyko technique as an adjunct to conventional management of asthma. Respir Med. 2008; 102 (5).

Надійшла 05.02.2020 